\title{
Status of Female Workers in Construction Industry in India: A
} Review

\author{
Kalpana devi ${ }^{1}$ \& U.V.Kiran ${ }^{2}$ \\ Student ${ }^{l} \&$ Assistant Professor ${ }^{2}$ \\ Department of Human Development and Family Studies, School for Home Sciences. Babasaheb Bhimrao \\ Ambedker University, Lucknow.
}

\begin{abstract}
Construction industry provides job opportunity to large number of skilled as well as unskilled workforce. The workforces employed in the industry have to face several difficulties at the work place. Several issues related to health, job stress, and injuries at work place are the major concern of the research among researchers. The present study is review of past research work related to the women work force employed in construction industry in India. The major focus of the study is to identify the key factors related to the status of female worker in the industry. Women work as unskilled labour and face several other difficulties in comparison to males. Sexual harassment, gender biasness, wage discrimination are the major factor due to which the working environment becomes difficult for them in the industry and women's are remains at same level of skill even after working few number of years .
\end{abstract}

Keywords: Construction industry, health, injuries, job stress.

\section{Introduction}

Women are almost unskilled labourers and they face serious problems related to work, viz., wage discrimination, gender and sexual harassment, unhealthy job relationship, lower wages; despite these, construction industry over whelmingly attracts female workers. Their skills are never upgraded as they are allowed to perform only certain types of work and usually they assist the male work force. India is one of the fastest growing economies of the world. There are several policies adopted by Government of India for the development of infrastructure for the country's economic development. Construction industry is the key for the success of the globalization of Indian economy .Construction sector is providing employment to $7 \%$ of total world employment. Today Indian construction industry employs about 31 million people and creates assets worth over Rs 200,000 million (India Infra Guru, 2008; GOI, 2008a) annually. In India, it is the largest employer of unorganized labour next to agricultural sector (Laskar and Murty, 2004). The contribution of construction sector in India to the GDP at factor cost in 2006-07 was Rs. 1,965,550 million, registering an increase of $10.7 \%$ from the previous year and the share of construction in GDP has increased from $6.1 \%$ in $2002-03$ to $6.9 \%$ in 2006-07 (GOI, 2008).

Around $16 \%$ of the India's working population depends on building construction for its livelihood and the Indian construction industry today employs about 31 million people and creates assets worth over rs 200,000 million (India Infra Guru,2008; GOI,2008a)annually. However, the construction industry in India is facing a huge shortage of manpower. The strength of skilled workforce in construction has dwindled substantially from $15.34 \%$ in 1995 to $10.57 \%$ in 2005 , whereas relative proportions of unskilled workers have gone up from $73.08 \%$ in 1995 to $82.45 \%$ in 2005 (GOI, 2008b). These construction labourers are one of the most vulnerable segments of the unorganized sector as there is no permanent job opportunity for them. The construction industry has an annual turnover of Rs 2,10,000 crores.

Construction workers are the backbone of the economy as they create the infrastructure necessary for industrial growth. In a globalizing economy, it is they who are constructing the new economy. India's three crore construction workers are literally the builders of modern India. They contribute in infrastructural development of India by building the roads and highways, the railway tracks and airports and ports, the IT cities, the call centre's and mega malls that are creating new forms of wealth today. It is they who are laying the cables for a rapidly expanding country-wide telecommunications network that connect the vast sub-continent and make India one country, to shorting the distance and supporting the business activitely in order to upgrade the economic development. Yet these workers, who are creating the base of the new economy, lives in a time warp, trapped in low skilled, low paid, insecure working conditions. About one-third of these workers are women and children. Women are almost unskilled labourers they face serious problems related to work, viz., wage discrimination, gender and sexual harassment, unhealthy job relationship, lower wages, etc despite all these, construction industry overwhelmingly attracts female workers. Their skills are always at the same level and are not upgraded as they assist only the male work fare the workplace. Their husbands are often drunkards or are 
found to have other sexual partners and find themselves in debt trap, due to these factors women are unable to strengthen their skills and economic position in the industry. The female employment in the construction industry is very high, even though they work only as the helpers or unskilled workers. The present study aims at reviewing the existing literature to look for various issues of discrimination due to gender.

\section{Literature Review}

The review of literature is pertaining to some of the important articles and survey documented by various researcher regarding the construction industry and women's status. The focus of review is on the factors such as gender biasness, sexual harassment, family conditions of the women working in construction industry .The variability in labour absorption in construction workers is much more pronounced for women than for men. It has often been noticed that whenever there is high demand for labour in this sector, the female employment rates is much higher than that of males. On the other hand, whenever there is any shrinkage in the workforce, female workers are the one who will be removed from the work force than compared to males (Shramshakti Report). It appears that women construction workers form a buffer which provides the cushion to industry and as soon as the situation comes under the control they are shifted towards some other industry. The literature review is categorized in to following sections to have an in depth insight regarding discrimination of construction workers based on gender-

A. Women's Employment.

B. Gender Bias in Construction Sector.

C. Wage Discrimination.

D. Sexual Harassment at Work place.

E. Social and education context.

F. Health Hazards.

A. Women's Employment

When it comes to female employment, however, the trends revealed by statistical analysis are more mixed.

Public sector employment and Private sector employment of women in construction industry (in thousands).

\begin{tabular}{|l|l|l|l|}
\hline Year & 1981 & 1991 & 2000 \\
\hline Public sector & 49.8 & 55.3 & 63.2 \\
\hline Privet sector & 9.5 & 6 & 4 \\
\hline
\end{tabular}

There have been some attempts to measure the intensity of work done by women in construction work as per the studies conducted by Madhok (2005) reported the status of women workers in the construction industry National commission for women New Delhi as under.

$>$ In concreting, it was found that in 15 minutes, about 55 bundles, each weighing 7-8 $\mathrm{kg}$, passed through the hands of women. In an 8-hour shift, therefore, an incredible 32,000 kg. Would have passed through a woman worker's hands.

$>$ For masonry work, women carried 9-12 bricks (each weighing $2.5 \mathrm{~kg}$ ) on their head and moved with grace and skill along the scaffolding.

$>$ While doing earth work women carried on their head $15 \mathrm{~kg}$. of mud and walked 30 feet to deposit the mud and return. In an hour this was repeated 180 times. In an 8-hour shift a woman on average would have walked about $13 \mathrm{kms}$ carrying about $21000 \mathrm{~kg}$. of mud.

$>$ While using a crowbar to dig into the earth, women would do this15 times a minute, matching the efficiency of able bodied men.

$>$ In curing, women were found carrying water in pots each weighing $8 \mathrm{~kg}$., 15 times per hour to pour over concrete structures.

$>$ In breaking Jallis, women used an iron hammer 52 times per minute and went on doing this for a 9-hour shift with a one hour break in between.(Girija and Geetha 1989)

\section{B. Gender Bias in Construction Sector}

Women constitute half of the construction workers in India as semi-skilled / skilled jobs in other industries but in the construction industry, women are employed mostly as unskilled labourers (GOI. 2008a). They perform various unskilled jobs in the industry like cleaning building sites, carrying bricks, gravel, mortar and water up to the skilled carpenters and masons, irrespective of the number of years they worked, they are not upgraded from unskilled to skilled as males (Jhabvala \& Kanbur, 2002; Baruah, 2008). This mindset has led to gender discrimination in this sector for work allocation and wage distribution (Suchitra and Rajshekhar, 2006). Such anti-women attitudes and discrimination further complicate the workplace culture of these women labour. They live very tough life and do not enjoy equality of status and social justice for which they actually deserve. 


\section{Wage Discrimination}

Government fixed the wages for the unskilled and skilled labors for the public sector unit as well as the private sector on the basis of work performed in terms of hours. But unfortunately the industry works as in form of contract which provide the cost saving for government which ultimately offer opportunity to the contractors to negotiate the wages .Males who are unskilled and skilled negotiate higher than female indicating gender biasness.

The previous surveys conducted in various parts of the country throw light on this fact, some of them are as, Sixty percent of the women earn wages between Rs 61 and 70 per day (Delhi).

Women construction workers said there was discrimination in wages, with the contractors paying them Rs 80 per day while paying men Rs 100 per day (Mumbai).At the end of a day's work, men get paid Rs 60-70 but women get only Rs 30-40.(Patna).

Women face discrimination on the job because even if they have the same skills as the men they are not given the same work. Thekedars act tough and do not pay wages regularly, handing out only enough for daily expenses and commuting. It is not safe for women to stand for a couple of hours at the naka. Thekedars and others eye them, harass them.

\section{Sexual Harassment at Work Place}

Sexual harassment is a serious problem for female construction workers. 74 per cent of the respondents reported sexual harassment at work place. Studies also revealed that insecure nature of employment, particularly for women, creates a vicious trap in which women are forced to please a subcontractor in order to get work. It is evident that the overwhelming majority of women in the industry are young, being between the ages of 16-40 years. (Rai and Sarkar 2012). A survey conducted in Punjab reported that of the respondents $(55.00 \%)$ were in the age group of 21-30 years, followed by 37.50 percent who were of $31-40$ years (Bharara $\mathrm{K}$,et al . Most of the workers are married. Women of these age group have the capacity to do hard work and easily harassed by the contractor. Thekedars and employers usually prefer to employ younger women whom they may exploit sexually. An extremity of demands of thekedars (contractors) can be estimated from the fact that to get employment, some of the older age workers force other poor young girls to please contractors; as in turn contractors has promised her to provide regular employment opportunity and 20 per cent extra commission on her wage for next whole year. Some reports state that they are exploited by thekedars both sexually as well as economically, many times such they face desertion of their own spouses and ultimately the loose the jobs.

Findings further noticed that despite the prevalence of such harsh and hostile work culture, low level of job satisfaction and unhealthy job relationship, construction industry overwhelmingly attract female labourers next only to agricultural sector. On the question why despite, such a hostile workplace, a large number of womenfolk take job at sit?

There are several factors responsible for that, some of the factors are identified by the researchers in past which are family income, self motives, social forces, season etc. The findings reveal that about $46 \%$ of respondents reported that they do not have any other option, as they are widows or abandoned by their husband, or if husband is there, he is either drunkard or unemployed, therefore to meet the dire needs of family and to support children they have to take job at site. Another group (4\%) is forced by poverty while 10per cent are working to improve their economic status or helping other existing members of family in construction industry. Only $4 \%$ of the female workers join the jobs at their own choice. It is largely noticed that or one hand where this womenfolk lack any particular skill, on another they are forced to work in unfavorable situations.

\section{E. Social and education Context}

Based on three surveys of Delhi, Andhra Pradesh and Rajasthan, the picture emerges about women construction workers and their social context comes out as, Harijans and tribals are the largest groups represented, although they comprise only 15 percent and 5 percent of the Indian population respectively. It is apparent that the rural groups most likely to migrate in search of work are those who own the least land or are landless labourers.

SC and ST are the largest landless groups in rural India, they also lacks the skills as well other education. The construction Industry is well suited for them according to their status, so they are likely to comprise a significant section of construction workers. Ninety-six percent of the construction workers in Delhi are Harijan migrant labourers from Rajasthan; Harijans and tribals together comprised 90 percent of the Andhra sample, most of the women are young (average age 25) having joined the workforce before they reached their teens. Almost all are illiterate (Construction Work. In .Women and Work: Continuity and Change. Edited by Lebra, Paulson, Everett, Promilla \& Co, 1984). Demographic picture has changed somewhat, with, for instance, more construction workers coming to Delhi from other states, comprising of scheduled Castes and Tribes. 


\section{F. Health Hazards}

The women workers at certain points were going through a number of job stresses like sexual harassment, being jobless, gender-based discrimination, proneness to different health hazards, physical problems, insomnia, nausea, headache, and other adverse outcomes. It is seen that at the work place they do not have any privacy for sanitation. Both male and female workers work together. Due to free mixing with the male co-workers they might get Sexually Transmitted Diseases (Tiwari and Ganopadhyay 2011).

Specifically targeting to female construction workers, the impact of specific job stressors on women in the construction industry and the job stressors examined, were classified into areas of "Job/Task Demand", "Organizational Factors" and "Physical Conditions. Female construction workers differ from female workers in most other industries because their work setting is non-traditional. Therefore, in addition to the effects of classic job stressors that have been studied in women working in traditional jobs, there is possibility of very different perceptions of dominant job stressors and their levels of effect by female construction workers. It was also found that skill underutilization as well as having to over-compensate to prove oneself on the job were associated with psychological symptoms. While support from co-workers and supervisors did not moderate the association between control and gender based harassment and discrimination, it did have a significant effect of job satisfaction (Goldenhar et.al 1998).

\section{Conclusion}

In India as the literacy level among women is increasing, but still the gender biasness is a crucial factor for the discrimination which starts from the house when the girl is born and continues in each stage of life. In India a large group of female unskilled worker works in the rural area as agriculture laborer as soon as the season ends, they shift to the construction industry which increases their employment level in the industry by doing so they support to their husband in income generation, for meeting their house hold expenditure. Most of them belong to the migrant families, their family members also create obstacle for them due to lack of education, Males are drunkards which make difficulty in meeting their expenditures. Their job is not easy, within the industry as they have to face several adverse situations such like sexual harassment, wages discriminations injuries and deceases are the major factors due to which women's even though works hard, but lag behinds the men and remains unskilled even after hardship a lot of years. The scenario only can be changed with the government intervention, by implementing the policies strictly. The contractors should be cheeked from time to time .Stem action has to be taken against all those who harasses the employees. The status of the women only can be improved when major transition in the society occurs and that can be achieved by mind set transition.

\section{References}

[1]. Aadya and Kiran, U.V. (2013), Occupational Stress of Women Workers in Unorganized Sector, International Journal of Scientific and Engineering Research, 4(3),3-13.

[2]. Bharara, K., Sandhu, P., and Sidhu, M. (2012). Issues of Occupational Health and Injuries among Unskilled Female Labourers in Construction Industry: A Scenario of Punjab State.

[3]. Das, D. K. (1985). Sex Discrimination against Female Workers in Unorganized Sector, Indian Journal of Industrial Relations, 21(2), 232-244.

[4]. Girija, R. and Geetha, R. et al.)(1989). Socio-Economic Conditions of Construction Workers in Tamil Nadu, Report submitted to ICSSR,(Mimeo).

[5]. Kumari, N and Kiran, U.V.(2012). Occupational profile of child labour in Chikankari Industry, Advanced Research Journal of Social Science, 44 (4), 247-250.

[6]. Madhok, S. (2005). Report on the status of women workers in the construction industry National commission for women New Delhi.

[7]. Reddy, D. N. (1979). Female Work Participation in India: Facts, Problems, and Policies Indian Journal of Industrial Relations, 15(2), 197-212.

[8]. Richard, D. L. and Gelleny, R. (2007). Women's Status and Economic Globalization, International Studies Quarterly, 51(4), 855876.

[9]. Rai, A. and Sarkar, A. (2012). Workplace Culture \& Status of Women Construction Labourers; A case study in Kolkata, West Bengal, Indian Journal of Spatial Science 3.0(2) Winter Issue, 44 - 54.

[10]. Shivakumar, M.S., Sheng, Y.K. and Weber, K.E. (1991). Recruitment and Employment Practices in Construction Industry: $A$ Case Study of Bangalore: Economic and Political Weekly 26 (8), M27-M40.

[11]. Self Employed Women's Association (2000). Labouring Brick by Brick: A Study of Construction Workers.

[12]. Tiwari, G., Gangopadhy, P.K. (2011). A review on the occupational health and social security of unorganized workers in the construction industry, Indian Journal of Occupational and Environment Medicine 5(1). 